\title{
Terminally differentiated memory $T$ cells are increased in patients with common variable immunodeficiency and selective $\operatorname{IgA}$ deficiency
}

\author{
JANA NECHVATALOVA ${ }^{1}$ TOMAS PAVLIK', JIRI LITZMAN ${ }^{1}$, MARCELA VLKOVA ${ }^{l}$ \\ 'Department of Clinical Immunology and Allergology, St Anne's University Hospital, and Faculty of Medicine, Masaryk University, Brno, \\ Czech Republic \\ ${ }^{2}$ Institute of Biostatistics and Analyses, Masaryk University, Brno, Czech Republic
}

\begin{abstract}
Introduction: Previous studies showed that several lymphocyte abnormalities seen in the most frequent symptomatic immunoglobulin deficiency, common variable immunodeficiency (CVID), were also observed in a genetically related asymptomatic disorder - selective IgA deficiency (IgAD). In this study we searched for abnormalities in the differentiation stages of $T$ cells as well as for similarities of these abnormalities in CVID and IgAD patients.

Material and methods: Using flow cytometry in 80 patients with IgAD, 48 patients with CVID, and 80 control persons we determined T-lymphocyte subsets: both CD4 and CD8 were divided into the naïve $C D 45 \mathrm{RO}^{-} \mathrm{CD} 27^{+}$, early differentiated $\mathrm{CD} 45 \mathrm{RO}^{+} \mathrm{CD} 27^{+}$, late differentiated $\mathrm{CD} 45 \mathrm{RO}^{+} \mathrm{CD} 27^{-}$and fully differentiated effector $C D 45 R O^{-} C D 27^{-}$memory $T$ cells, as well as Treg cells, defined as $C D 4^{+} C$ D25highCD127low T cells.

Results: An increase of $\mathrm{CD}^{+}$and $C D 8^{+}$late differentiated memory cells was observed comparing CVID patients to controls, as well as comparing IgAD patients to controls. In CVID patients an increase of $\mathrm{CD}^{+}$early differentiated memory cells, a decrease of $C D 8^{+}$intermediate memory cells, and $C D 4^{+}$ and $C D 8^{+}$naïve cells were found as well. The abnormalities in IgAD patients might be explained by higher CMV seropositivity observed in our IgAD. We confirmed the repeatedly published decrease of Treg cells in CVID patients, while Treg cells in IgAD patients were increased compared to controls.

Conclusions: Our results show T-cell activation not only in CVID, but also in IgAD patients. The increase in IgAD patients may be influenced by a more frequent CMV infection in our group of IgAD patients.
\end{abstract} $C M V$.

Key words: IgA deficiency, common variable immunodeficiency, T-lymphocyte subpopulations,

(Centr Eur J Immunol 2017; 42 (3): 244-251)

\section{Introduction}

The pathogenesis of selective IgA deficiency (IgAD, serum IgA $<0.07 \mathrm{~g} / 1$, and normal other immunoglobulin isotype levels), the most frequent immunoglobulin deficiency in Caucasians, is unknown [1]. Patients with IgAD are asymptomatic in most cases, or they may suffer from recurrent infections of the respiratory tract; also the frequency of autoimmune diseases is increased in IgAD [2]. Compared to this, in the most frequent symptomatic hypogammaglobulinaemia: common variable immunodeficiency (CVID), besides $\operatorname{Ig} \mathrm{A}$, also IgG and frequently IgM serum levels are decreased [3]. The clinical manifestation of CVID is diverse, the patients suffer from recurrent and complicated infections mainly of the respiratory tract, but also from autoimmune diseases, splenomegaly, gastrointestinal diseases, or systemic granulomatous disease [4-6]. CVID seems to be a group of different diseases with similar clinical and laboratory manifestation, and we cannot exclude a similar situation in IgAD. However, the occurrence of both diseases in affected families and the repeatedly described progression of IgAD to CVID suggest a similar genetic background of IgAD and CVID, at least in some cases [7, 8].

Various abnormalities in the number or function of $\mathrm{T}$ and $\mathrm{B}$ cells were described in patients with CVID [9-15].

Correspondence: Marcela Vlkova, Department of Clinical Immunology and Allergology, St Anne's University Hospital, and Faculty of Medicine, Masaryk University, Pekarska 53, Brno, Czech Republic, e-mail: marcela.vlkova@fnusa.cz Submitted: 11.01.2016; Accepted: 2.02.2016 
Assessing $\mathrm{T}$ cells, a decrease in $\mathrm{CD}^{+}$and an increase in $\mathrm{CD}^{+} \mathrm{T}$ cells were repeatedly described, also an increase in memory $\mathrm{CD}^{+} \mathrm{CD} 45 \mathrm{RO}^{+}[9,11,12]$, activated $\mathrm{CD} 4^{+} \mathrm{CD} 25^{+}$ $[11,12], \mathrm{CD}^{+} \mathrm{HLA}^{-\mathrm{DR}^{+}}[9,11-13], \mathrm{CD}^{+} \mathrm{CD} 38^{+}[11$, 12], terminally differentiated $\mathrm{CD} 8{ }^{+} \mathrm{CD} 57^{+}[9,12,13]$, or a decrease in, naïve $\mathrm{CD} 4{ }^{+} \mathrm{CD} 45 \mathrm{RA}^{+} \mathrm{CD} 27^{-}[11,12]$, and non-effector $\mathrm{CD}^{+} \mathrm{CD} 27^{+}[11], \mathrm{CD} 8^{+} \mathrm{CD} 27^{+}[11,12]$, or regulatory $\left(\mathrm{T}_{\text {reg }}\right) \mathrm{T}$ cells $[14,16]$ were reported. Although with a markedly less significant expression, some of these abnormalities in $\mathrm{T}[11,12]$ and $\mathrm{B}$ [10-12] cells were described in IgAD as well, showing that the immunopathogenesis of both diseases may be similar. The elevated numbers of activated $\mathrm{CD}^{+}$and $\mathrm{CD}^{+}$lymphocytes, but also higher serum neopterin [17] or soluble CD25 (sCD25) levels [18], point to the activation of the immune system in patients with CVID and possibly IgAD.

The development and maturation of T cells in periphery is a complex process, and various schemes are used to describe the differentiation stages of $\mathrm{T}$ lymphocytes in peripheral blood [19-21]. In our study, we intended to determine the T-cell differentiation stages spectrum in CVID and $\operatorname{Ig} \mathrm{AD}$ patients. For the differentiation stages of $\mathrm{T}$ cells we used the scheme described by Maenetje [22] based on the determination of CD45RO and CD27. Because our previous studies showed that many abnormalities in B-cell subsets seen in CVID were also observed in IgAD patients [10-12], we have also searched for similarities and dissimilarities in T-cell differentiation stages in CVID and IgAD.

\section{Material and methods}

Peripheral blood was obtained from 80 patients with IgAD (27 males and 53 females; aged 18-70, median 33 years), 48 patients with CVID (19 males and 29 females; aged 19-75, median 45 years), and 80 healthy controls (27 males and 53 females; aged 18-74, median 32 years).

The control group was mainly represented by relatives of hospital employees and students of medicine. The patients fulfilled the European Society for Immunodeficiencies (ESID) and the Pan-American Group for Immunodeficiency's (PAGID) diagnostic criteria for CVID and IgAD [23].

More detailed characteristics of these groups were described previously [10].

\section{T-cell analysis}

Five millilitres of peripheral blood taken in ethylenediaminetetraacetic acid (EDTA) was stained with monoclonal antibodies and analysed using flow cytometry methods. Forty-five microlitres of the blood was treated with 5-10 $\mu \mathrm{l}$ of the appropriate antibodies for 30 minutes at laboratory temperature in the dark. The blood was then processed for automated lysis, stabilisation, and fixation of the sample by a TQ-PREP workstation (Beckman Coulter, Miami, USA).

\section{Flow cytometry analysis}

Immunophenotyping was performed by flow cytometric analysis (five-colour flow cytometer FC-500; Beckman Coulter with CXP software).

For the staining of T-lymphocyte differentiation stages the following antibodies were used: R-Phycoerythrin-Cyanine 7 (PC7)-conjugated anti-CD4, anti-CD8, Phycoerythrin-Texas red X (ECD)-conjugated anti-CD8, anti-CD45RO; PC5-conjugated anti-CD27, and anti-CD25 (all from Beckman Coulter). For the staining of $\mathrm{T}_{\text {regs }}$ we used anti-CD4 PC7, anti-CD127 PE, and anti-CD25 PC5 (Beckman Coulter).

T lymphocytes, both CD4 and CD8, were divided into naïve $\mathrm{CD} 45 \mathrm{RO}^{-} \mathrm{CD} 27^{+}$, early differentiated (ED)

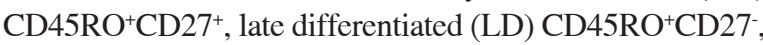
and fully differentiated effector (FD) CD45RO-CD27- memory $\mathrm{T}$ cells. In $\mathrm{CD} 8^{+}$cells a unique $\mathrm{CD} 45 \mathrm{RO}^{-\mathrm{CD}} 27^{\mathrm{dim}}$ intermediate population was determined as well [22] (Fig. 1). $\mathrm{T}_{\text {reg }}$ cells were defined as $\mathrm{CD} 4{ }^{+} \mathrm{CD} 25^{\text {high }} \mathrm{CD} 127^{\text {low }}[24]$ in accordance with recent studies that demonstrated that the description of $\mathrm{T}_{\text {regs }}$ as a $\mathrm{CD} 4{ }^{+} \mathrm{CD} 25^{\text {high }} \mathrm{CD} 127^{\text {low }}$ phenotype correlates well with FoxP3 expression $[25,26]$.

\section{Autoantibodies}

Enzyme-linked immunosorbent assay (ELISA) was used for the determination of antibodies: anti-thyroid peroxidase (AESKULISA a-TPO, Aesku.Diagnostics, Wendelsheim, Germany), anti-thyroglobulin (AESKULISA a-TG, Aesku.Diagnostics), anti-tissue transglutaminase antibodies (AESKULISA tTg-G, AESKULISA tTg-A, Aesku.Diagnostics), and the rheumatoid factor (AESKULISA Rf-AGM, Aesku.Diagnostics). Anti-nuclear antibodies were tested by indirect immunofluorescence (IIF) using HEp-2 cells (HEp-2 kit, Euroimmun, Lübeck, Germany); anti-gastric parietal cells, anti-reticulin, and anti-smooth muscle antibodies were determined using the rat liver/ kidney/stomach IIF kit (Autoantibodies RL/RK/RS kit, Orgentec, Mainz, Germany).

\section{Detection of CMV-specific antibodies}

IgG anti-CMV antibodies were determined by ELISA using the EIA CMV IgG kit (Test-Line, Brno, Czech Republic). The cut-off of positivity was used upon the manufacturer's instruction.

\section{Statistical analysis}

Statistical significance was determined using a nonparametric Mann-Whitney test for comparisons of two independent samples. A standard level of statistical significance $p=0.05$ was used. The results are expressed as median (fifth to $95^{\text {th }}$ percentile). All analyses were performed using Statistica 9.1 software (StatSoft Inc., Tulsa, USA) 

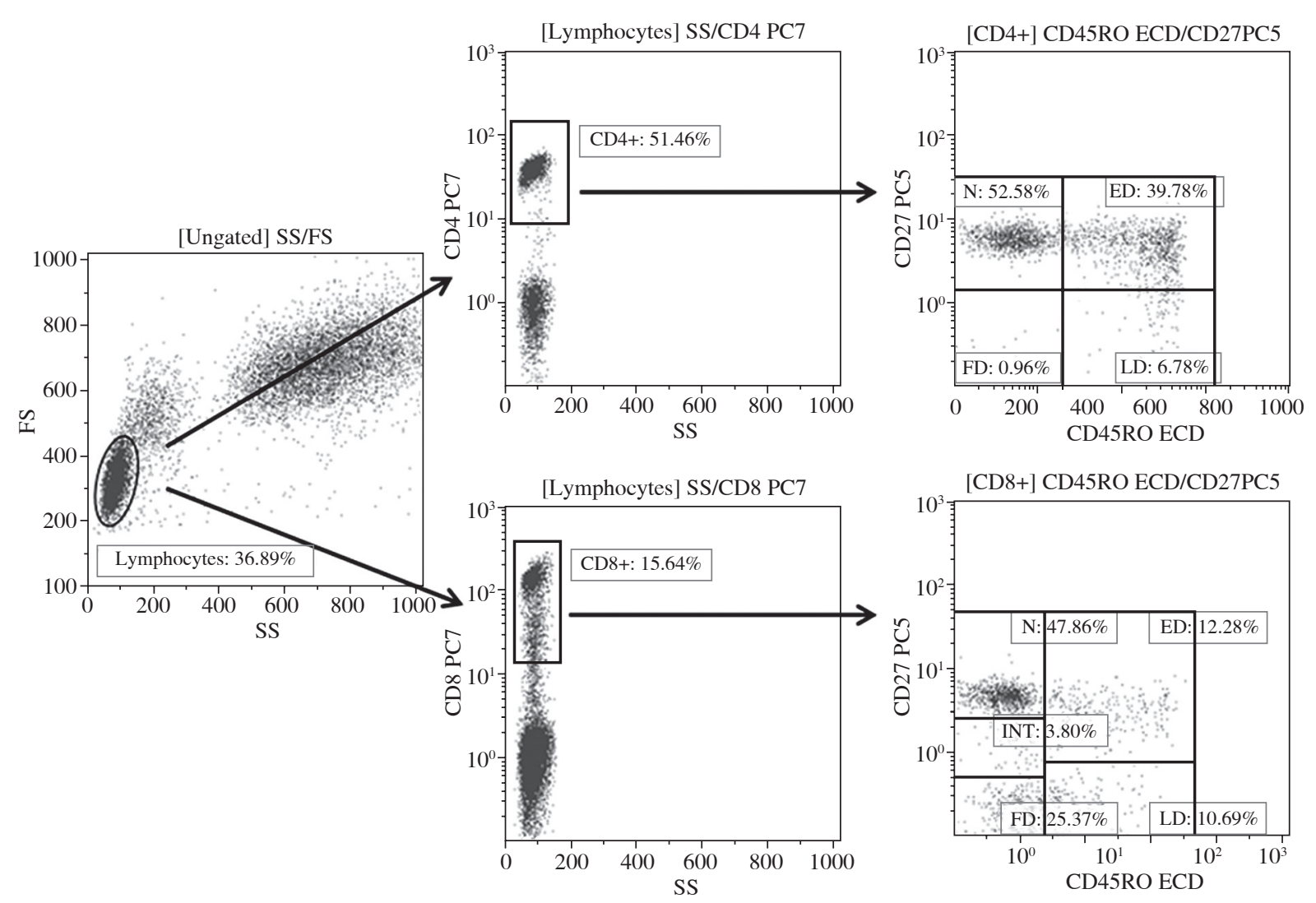

Fig. 1. Gating strategy for T-cell subsets. Gating is shown for a representative healthy donor. N naïve cells $\left(\mathrm{CD}^{-} \mathrm{RO}^{-}\right.$ $\left.\mathrm{CD} 27^{+}\right)$, ED early differentiated $\left(\mathrm{CD} 45 \mathrm{RO}^{+} \mathrm{CD} 27^{+}\right)$, LD late differentiated $\left(\mathrm{CD} 45 \mathrm{RO}^{+} \mathrm{CD} 27^{-}\right)$, FD fully differentiated effector $\left(\mathrm{CD}^{2} 5 \mathrm{RO}^{-} \mathrm{CD} 27^{-}\right)$, INT intermediate $\left(\mathrm{CD} 45 \mathrm{RO}^{-} \mathrm{CD} 27^{\mathrm{dim}}\right)$ memory T cells

and GraphPad Prism 5.04 software (GraphPad software Inc., La Jolla, USA).

The study was approved by the Ethics Committee of St. Anne's Faculty Hospital in Brno. Informed consent was obtained from all investigated individuals before the samples were drawn.

\section{Results}

\section{Late T-lymphocyte differentiation stages are increased in IgAD and CVID patients}

Comparing CVID patients to control persons, an increase of $\mathrm{CD}^{+}$and $\mathrm{CD}^{+}$late differentiated memory cells $\left(p<0.001\right.$ and $p<0.001$, respectively), $\mathrm{CD}^{+}$early differentiated memory cells $(p<0.001)$, and a decrease of CD8 ${ }^{+}$ intermediate memory cells $(p=0.001)$ and also of $\mathrm{CD}^{+}$ and CD8 ${ }^{+}$naïve cells $(p<0.001$ and $p<0.001$, respectively) was found. In patients with $\operatorname{IgAD}$ a significant increase of both $\mathrm{CD}^{+}$and $\mathrm{CD} 8^{+}$late differentiated memory cells ( $p=0.006$ and $p<0.001$, respectively) and a decrease in
$\mathrm{CD}^{+}$naïve cells $(p=0.026)$ were documented as compared to healthy control persons (Fig. 2).

\section{Frequency of CMV-specific antibodies is increased in IgAD patients}

Since previous studies showed increased numbers of terminally differentiated memory $\mathrm{T}$ cells in patients with CMV infection [27, 28], we determined CMV IgG antibodies in the sera of control persons and patients with IgAD. Using IgG as a marker of CMV positivity, $40 \mathrm{IgAD}$ patients (aged 18-70, median 37.5 years) and 27 control persons (aged 19-74, median 39 years) were seropositive while 38 IgAD patients (aged 18-54, median 26.5 years) and 52 controls (aged 18-71, median 28 years) were seronegative, the difference between IgAD patients and controls being significant ( $p=0.030$, chi-square test).

We observed an increase in late differentiated $\mathrm{CD} 8^{+}$ cells in seropositive IgAD patients compared to seropositive control persons $(p=0.005)$, while there were no significant differences when comparing other subsets in seropositive IgAD patients to seropositive controls. When 


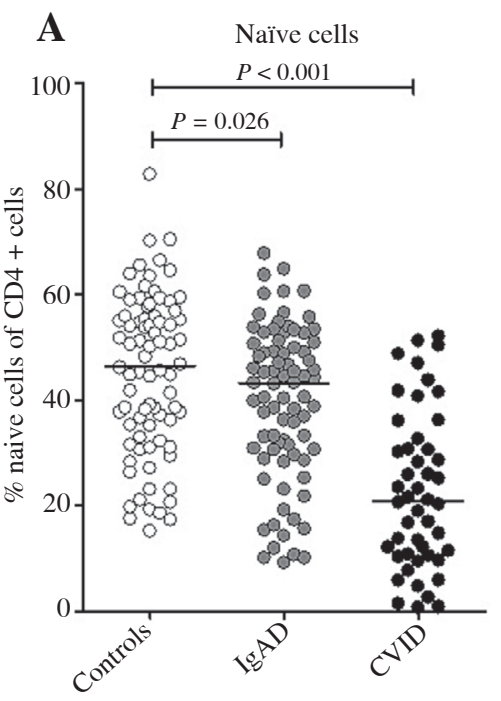

D Fully differentiated memory cells

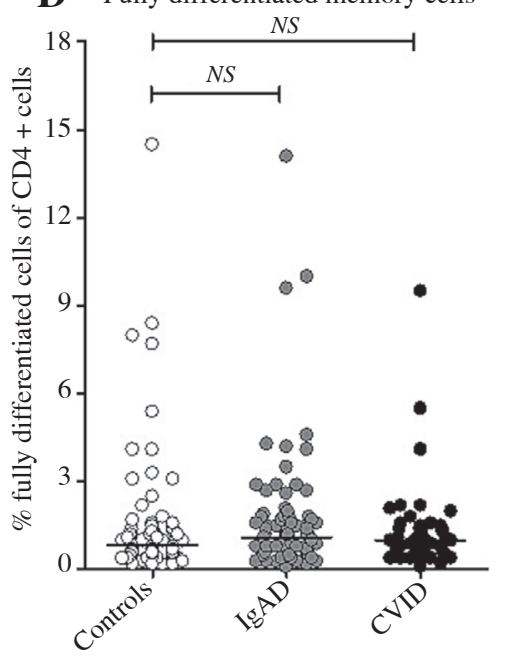

G Intermediate memory cells

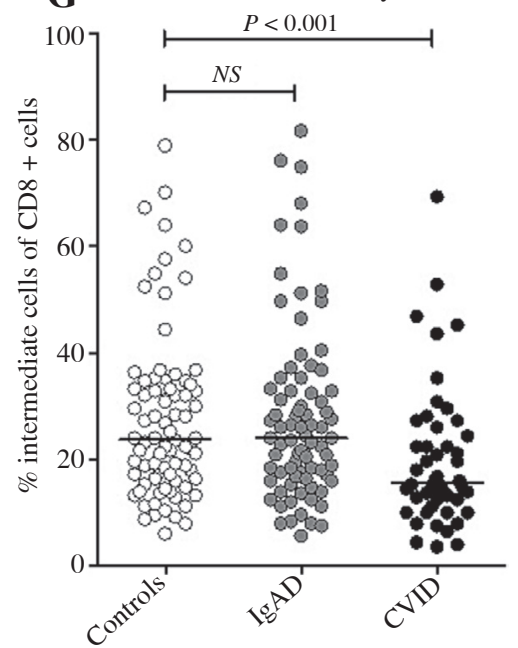

B Early differentiated memory cells
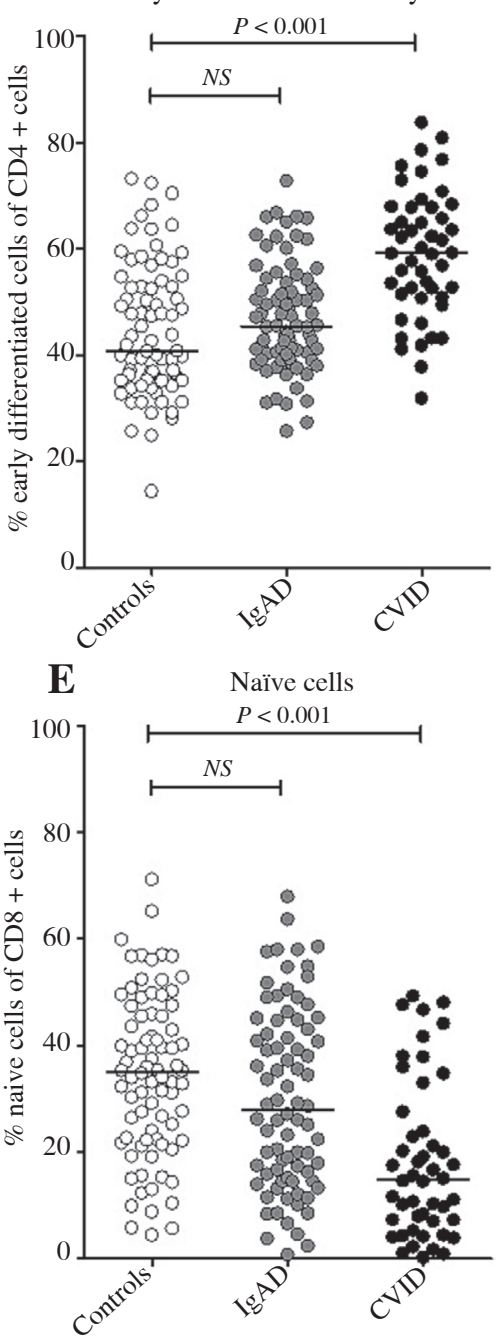

H Late differentiated memory cells

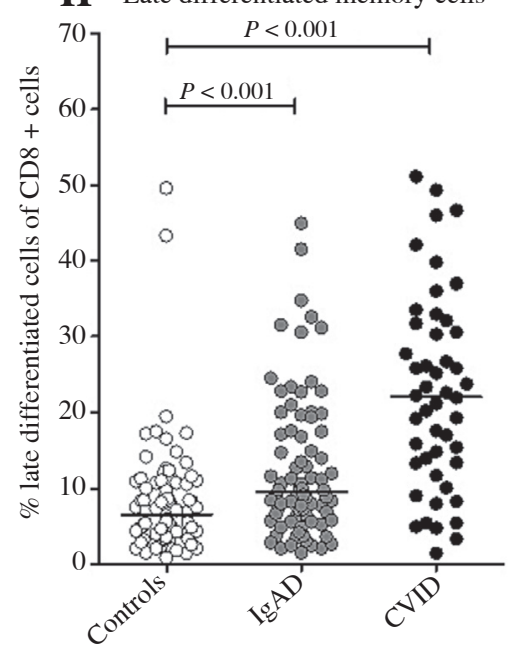

C Late differentiated memory cells

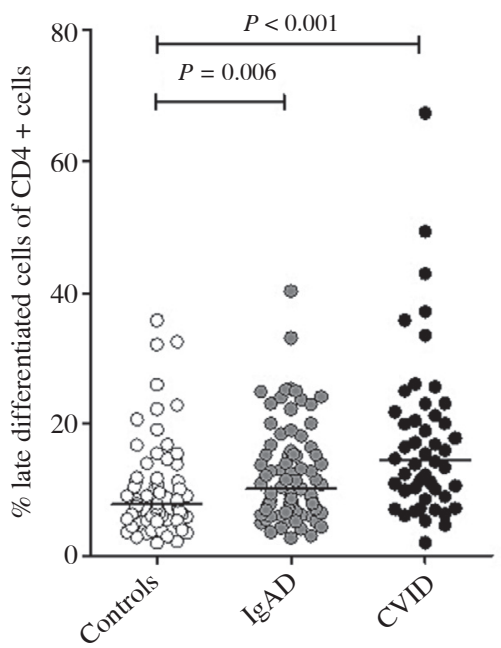

F Early differentiated memory cells

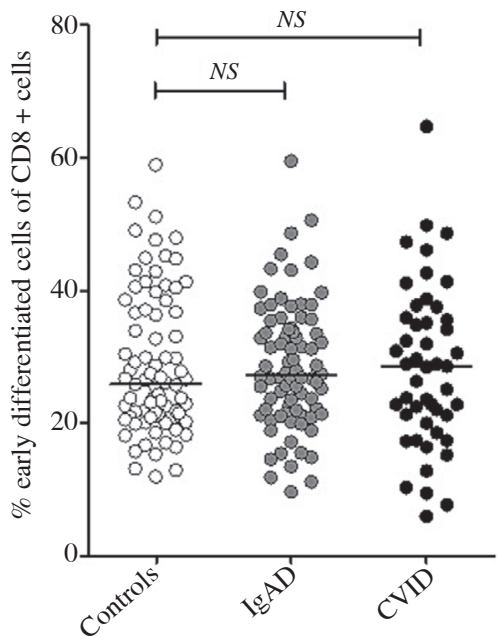

I Fully differentiated memory cells

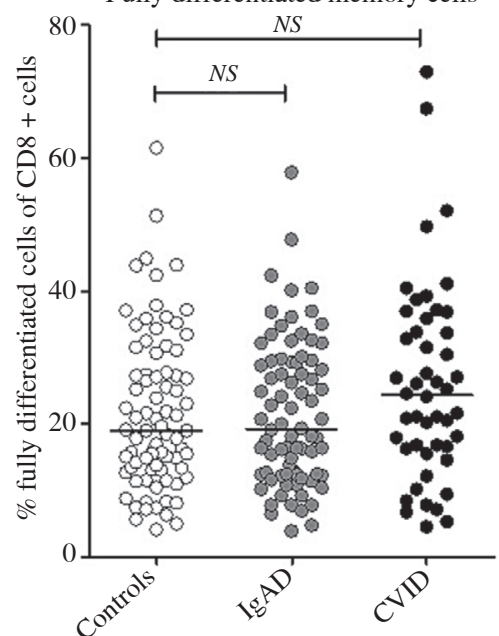

Fig. 2. Distribution of T-lymphocyte differentiation subsets in control persons and patients with IgAD and CVID. Naïve $\left(\mathrm{CD} 45 \mathrm{RO}^{-} \mathrm{CD} 27^{+}\right) \mathrm{CD}^{+}$and $\mathrm{CD} 8^{+}$cells $(\mathrm{A}, \mathrm{E})$, early differentiated memory $\left(\mathrm{CD} 45 \mathrm{RO}^{+} \mathrm{CD} 27^{+}\right) \mathrm{CD}^{+}$and $\mathrm{CD} 8^{+}$cells $(\mathrm{B}$, $\mathrm{F})$, intermediate memory $\left(\mathrm{CD} 45 \mathrm{RO}^{-} \mathrm{CD} 27^{\mathrm{dim}}\right) \mathrm{CD}^{+}$cells $(\mathrm{G})$, late differentiated memory $\left(\mathrm{CD} 45 \mathrm{RO}^{+} \mathrm{CD} 27^{-}\right) \mathrm{CD}^{+}{ }^{+}$and $\mathrm{CD}^{+}$cells $(\mathrm{C}, \mathrm{H})$, fully differentiated memory $\left(\mathrm{CD} 45 \mathrm{RO}^{-} \mathrm{CD} 27^{-}\right) \mathrm{CD} 4^{+}$and $\mathrm{CD}^{+}$cells $(\mathrm{D}, \mathrm{I})$. Horizontal lines indicate group medians; intergroup differences were analysed using Mann-Whitney test 
we compared all $\mathrm{CD} 4^{+}$and $\mathrm{CD} 8^{+}$subsets in seronegative IgAD patients to the seronegative control group, we found only a very slight decrease of $\mathrm{CD}^{+}$fully differentiated memory cells $(p=0.042)$ in IgAD patients; no significant changes in other subsets were shown. When we compared CMV-seropositive to CMV-seronegative IgAD patients, we found a decrease of both $\mathrm{CD}^{+}{ }^{+}$and $\mathrm{CD} 8^{+}$nadve cells (in both cases $p<0.001$ ), a decrease in $\mathrm{CD}^{+}$early differentiated memory cells $(p=0.030)$, an increase in $\mathrm{CD}^{+}$ and $\mathrm{CD}^{+}$late differentiated (in both cases $P<0.001$ ) and fully differentiated ( $p=0.038 ; p<0.001$, respectively) memory cells. Similar findings were obtained when comparing seropositive to seronegative controls: a decrease of both $\mathrm{CD}^{+}$and $\mathrm{CD} 8^{+}$naïve cells $(p=0.041 ; p=0.013$, respectively), and an increase in $\mathrm{CD}^{+}$and $\mathrm{CD} 8^{+}$late differentiated ( $p<0.001 ; p<0.001$, respectively) and fully differentiated ( $p=0.002 ; p=0.045$, respectively) memory cells in seropositive controls (Table 1 ).

\section{Age dependence of T-cell differentiation stages}

Correlating age and T-cell differentiation stages in control persons, we observed a decrease of $\mathrm{CD}^{+}$and $\mathrm{CD} 8^{+}$ naïve cells with age $(r=-0.326, p=0.003, r=-0.445$, $p<0.001$, respectively), while CD $4^{+}$early differentiated $(r=0.271, p=0.015)$ and $\mathrm{CD}^{+}$late differentiated $(r=$
$0.335, p=0.002)$ memory cells increased. These changes were more pronounced in IgAD patients with a decrease of both $\mathrm{CD}^{+}$and $\mathrm{CD}^{+}$nadve $(r=-0.598, p<0.001$; $r=-0.632, p<0.001$, respectively) and an increase of late differentiated memory cells $(r=0.4653, p<0.001$; $r=0.405, p<0.001$, respectively) $\mathrm{CD}^{+}$and $\mathrm{CD} 8^{+}$cells, $\mathrm{CD}^{+}$early differentiated $(r=0.537, p<0.001)$ and $\mathrm{CD}^{+}$ fully differentiated $(r=0.472, p<0.001)$ memory cells. In CVID patients a significant age-dependent correlation was observed in $\mathrm{CD}^{+}$nad've and late differentiated cells $(r=$ $-0.468, p<0.001 ; r=0.401, p=0.005$, respectively) and CD8 ${ }^{+}$nadive cells $(r=-0.461, p=0.001)$.

\section{$\mathbf{T}_{\text {reg }}$ cells are decreased in CVID but not IgAD patients}

The frequency of $\mathrm{T}_{\text {reg }}$ cells is shown in Fig. 3. We documented a decrease of $\mathrm{T}_{\text {reg }}$ cells in patients with CVID compared to controls $(p<0.001)$. Interestingly, we observed an increase of $\mathrm{T}_{\text {reg }}$ cells in IgAD patients compared to control persons $(p=0.039)$. We did not observe any significant changes in the frequency of $\mathrm{T}_{\text {reg }}$ cells when we compared $28 \mathrm{IgAD}$ patients with the presence of autoantibodies to 52 patients without the presence of autoantibodies $(p=0.912)$ or to 31 healthy donors with autoantibodies

Table 1. Frequency of T-cell subsets in $\mathrm{CMV}^{+}$and $\mathrm{CMV}^{-} \mathrm{IgAD}$ patients and healthy donors

\begin{tabular}{|c|c|c|c|c|c|c|c|c|}
\hline & $\begin{array}{c}\text { Controls } \\
\text { CMV+ } \\
\text { age (median) } \\
=39\end{array}$ & $\begin{array}{c}\text { Controls } \\
\text { CMV- } \\
\text { age (median) } \\
=28\end{array}$ & $\begin{array}{l}\text { IgAD CMV+ } \\
\text { age (median) } \\
\quad=37.5\end{array}$ & $\begin{array}{l}\text { IgAD CMV- } \\
\text { age (median) } \\
\quad=26.5\end{array}$ & $\begin{array}{l}\text { CMV+ } \\
\text { IgAD } \\
\text { vs. C }\end{array}$ & $\begin{array}{l}\text { CMV- } \\
\text { IgAD } \\
\text { vs. C }\end{array}$ & $\begin{array}{l}\text { IgAD } \\
\text { CMV+ } \\
\text { vs. } \\
\text { CMV- }\end{array}$ & $\begin{array}{c}\text { C } \\
\text { CMV+ } \\
\text { vs. } \\
\text { CMV- }\end{array}$ \\
\hline & $n=27$ & $n=52$ & $n=40$ & $n=38$ & $p$ & $p$ & $p$ & $p$ \\
\hline $\begin{array}{c}\text { CD4+CD45RO-CD27+ } \\
\text { (naïve) }\end{array}$ & $\begin{array}{c}38.5 \\
(17.4-61.6)\end{array}$ & $\begin{array}{c}51.2 \\
(21.1-66.4) \\
\end{array}$ & $\begin{array}{c}32.7 \\
(10.2-53.5) \\
\end{array}$ & $\begin{array}{c}48.5 \\
(15.7-63.7) \\
\end{array}$ & 0.086 & 0.590 & $<0.001$ & 0.041 \\
\hline $\begin{array}{c}\mathrm{CD} 4+\mathrm{CD} 45 \mathrm{RO}+\mathrm{CD} 27+ \\
(\mathrm{ED})\end{array}$ & $\begin{array}{c}45.4 \\
(31.1-60.5)\end{array}$ & $\begin{array}{c}40.3 \\
(29.1-68.2)\end{array}$ & $\begin{array}{c}47.4 \\
(31.0-65.8)\end{array}$ & $\begin{array}{c}42.8 \\
(31.0-66.0)\end{array}$ & 0.133 & 0.452 & 0.132 & 0.967 \\
\hline $\begin{array}{l}\mathrm{CD} 4+\mathrm{CD} 45 \mathrm{RO}+\mathrm{CD} 27- \\
\text { (LD) }\end{array}$ & $11.0(4.8-32.5)$ & $7.0(2.8-14.0)$ & $15.3(7.1-29.2)$ & $7.0(3.0-18.2)$ & 0.143 & 0.407 & $<0.001$ & $<0.001$ \\
\hline $\begin{array}{l}\text { CD4+CD45RO-CD27- } \\
\text { (FD) }\end{array}$ & $1.2(0.4-8.0)$ & $0.7(0.2-4.1)$ & $1.3(0.4-9.8)$ & $1.0(0.2-2.7)$ & 0.740 & 0.155 & 0.038 & 0.002 \\
\hline $\begin{array}{c}\mathrm{CD} 8+\mathrm{CD} 45 \mathrm{RO}-\mathrm{CD} 27+ \\
\text { (naïve) }\end{array}$ & $\begin{array}{c}26.5 \\
(5.6-50.8)\end{array}$ & $\begin{array}{c}37.1 \\
(15.0-57.0)\end{array}$ & $\begin{array}{c}17.4 \\
(3.1-47.7)\end{array}$ & $\begin{array}{c}40.1 \\
(8.5-63.6)\end{array}$ & 0.065 & 0.551 & $<0.001$ & 0.013 \\
\hline $\begin{array}{l}\text { CD8+CD45RO- } \\
\text { CD27dim (INT) }\end{array}$ & $6.8(2.3-13.5)$ & $5.6(2.4-16.0)$ & $5.2(2.0-15.3)$ & $6.6(2.1-16.0)$ & 0.292 & 0.354 & 0.163 & 0.563 \\
\hline $\begin{array}{c}\mathrm{CD} 8+\mathrm{CD} 45 \mathrm{RO}+\mathrm{CD} 27+ \\
\text { (ED) }\end{array}$ & $\begin{array}{c}25.5 \\
(13.1-47.6)\end{array}$ & $\begin{array}{c}26.8 \\
(15.7-51.0)\end{array}$ & $\begin{array}{c}26.7 \\
(12.3-43.1)\end{array}$ & $\begin{array}{c}32.4 \\
(18.8-50.5)\end{array}$ & 0.919 & 0.325 & 0.030 & 0.469 \\
\hline $\begin{array}{c}\mathrm{CD} 8+\mathrm{CD} 45 \mathrm{RO}+\mathrm{CD} 27- \\
(\mathrm{LD})\end{array}$ & $10.7(4.8-43.3)$ & $5.2(1.5-11.6)$ & $17.2(6.9-38.2)$ & $6.8(2.0-14.9)$ & 0.005 & 0.156 & $<0.001$ & $<0.001$ \\
\hline $\begin{array}{c}\mathrm{CD} 8+\mathrm{CD} 45 \mathrm{RO}-\mathrm{CD} 27- \\
\text { (FD) }\end{array}$ & $\begin{array}{c}26.5 \\
(7.3-43.7)\end{array}$ & $\begin{array}{c}17.0 \\
(6.2-43.8)\end{array}$ & $\begin{array}{c}27.1 \\
(10.9-45.0)\end{array}$ & $\begin{array}{c}12.8 \\
(4.7-32.6)\end{array}$ & 0.650 & 0.042 & $<0.001$ & 0.045 \\
\hline
\end{tabular}

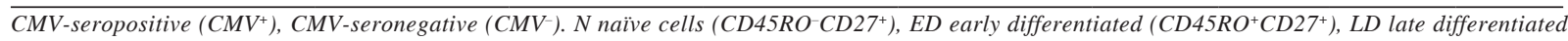

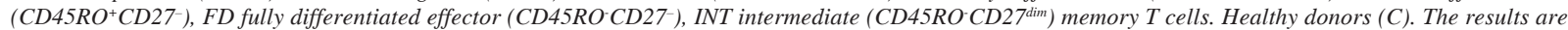
expressed as median ( $5^{\text {th }}$ to $95^{\text {th }}$ percentiles $)$. The $p$ value was obtained by the Mann-Whitney $U$ test 
( $p=0.509$ ) or the whole control group (with and without presence of autoantibodies) $(p=0.152)$.

\section{Discussion}

Due to the previously described activation of the T-lymphocytes immune system in patients with CVID we determined the degree of T-cell activation by the presence of differentiation stages of T-lymphocyte memory cells. The same T-cell differentiation stages were also determined in $\operatorname{IgAD}$ patients.

In IgAD patients we found a higher frequency of late differentiated memory cells, in both $\mathrm{CD}^{+}$and $\mathrm{CD} 8^{+}$cells. In patients with CVID the changes were more extensively expressed. Comparing CVID patients to controls, besides the increase of both $\mathrm{CD}^{+}$and $\mathrm{CD}^{+}$late differentiated cells, an increase of early differentiated $\mathrm{CD} 4^{+}$cells and a decrease of both $\mathrm{CD}^{+}$and $\mathrm{CD}^{+}$naïve cells were observed. Loss of both $\mathrm{CD}^{+}{ }^{+}$and $\mathrm{CD} 8^{+}$naïve cells (defined as $\mathrm{CD}^{2} 5 \mathrm{RA}^{+} \mathrm{CCR}^{+}$or $\mathrm{CD} 45 \mathrm{RA}^{+} \mathrm{CD}^{2} 2 \mathrm{~L}^{+}$) had also been described by Bateman et al. [29] and Giovannetti et al. [30], who proposed that the level of $\mathrm{CD}^{+}$naïve $\mathrm{T}$ cells might be considered as a parameter essential for classifying CVID due to its strong correlation with the severity of the disease and association with the "Freiburg" classification [31] based on B-cell differentiation markers.

This study showed in both IgAD and CVID patients an increase of terminally differentiated $\mathrm{CD} 8^{+}$cells, which are also supposed as a marker of virus infection-associated activation and memory maturation [22, 32, 33]. The link between $\mathrm{CD}^{+}$memory differentiation and immune activation was previously described [34]. This points to similarities between CVID and IgAD as observed in B-cell subpopulations [10]. This result is in contrast to the study by Bateman et al. [29], who did not find significant differences in any differentiated subset of T cells in the selective IgA-deficient group.

Several studies published an increase of terminally differentiated T cells in patients with HIV, leukaemia, or CVID, who suffered from CMV infection [22, 28, 33]. As our study showed an increase in the late differentiated memory cells in IgAD patients, we aimed to answer the question of whether the presence of CMV infection in IgAD patients was responsible for the above-mentioned observation. Therefore, we compared both CMV-seronegative and $\mathrm{CMV}$-seropositive IgAD patients to CMV-seronegative and CMV-seropositive control persons, and found only an increase of $\mathrm{CD}^{+}$late differentiated memory cells in CMV-seropositive $\operatorname{IgAD}$ patients. With the exception of a slight decrease of fully differentiated memory cells in IgAD patients, all other comparisons of the differentiated subsets between seropositive or seronegative groups were not significant. We suggest that the differences between the IgAD and the control groups can be, at least partially, associated with the increased CMV seropositivity in IgAD patients.

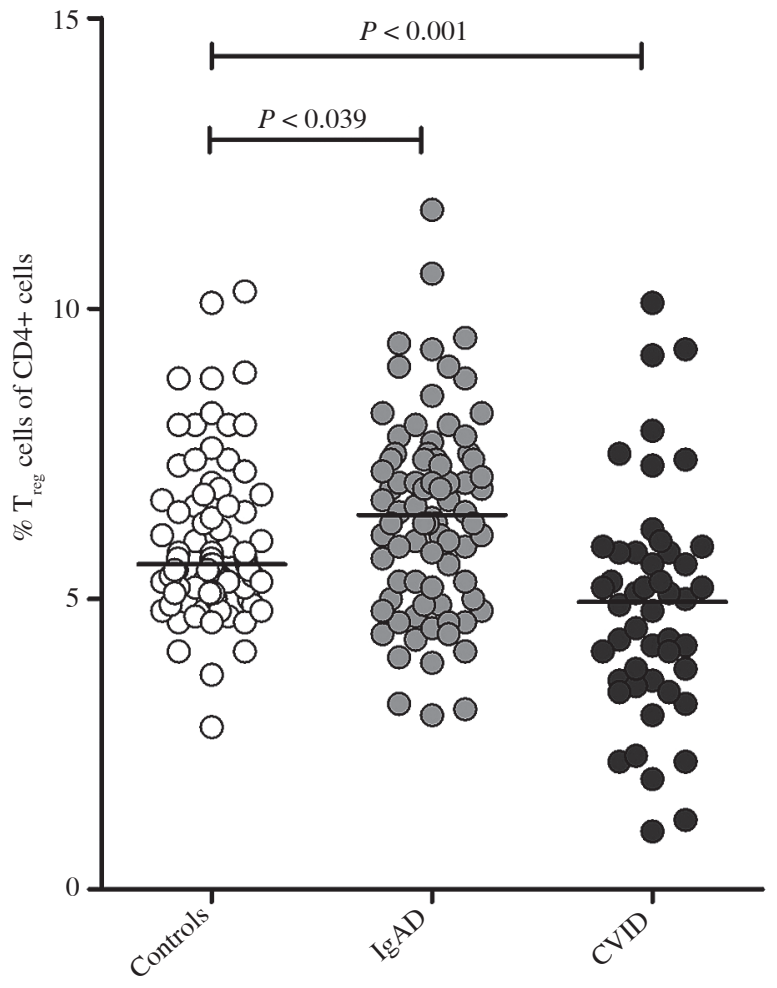

Fig. 3. Frequency of Treg cells in control persons and patients with IgAD and CVID. Horizontal lines indicate group medians; intergroup differences were analysed using Mann-Whitney test

The observation of the increase of CMV positivity in our IgAD patients was unexpected and, to our knowledge, no similar study was published. Although the groups of IgAD patients and control persons examined in our study were very similar as regards their age and sex, we cannot exclude a bias due to different socioeconomic status of the patients and control persons $[35,36]$ because our healthy donors were obtained mainly from the hospital staff, students of medicine, and relatives of the staff of our department, while the $\operatorname{IgAD}$ patients can be considered as a general, highly unselected, population. This finding deserves further confirmation.

$\mathrm{T}_{\text {reg }}$ cells play a critical role in suppressing the response of the immune system to self-antigens [37]. Previous studies showed decreased numbers of $\mathrm{T}_{\text {regs }}$ in CVID [14, 16], mainly in patients with autoimmune diseases [38]. We confirmed the decrease of $\mathrm{T}_{\text {reg }}$ cells in patients with CVID described previously. In contrast to CVID, surprisingly, there were increased numbers of $\mathrm{T}_{\text {regs }}$ in IgAD patients compared to control persons. Our observation is in agreement with the similar tendency recently published for IgAD patients by Bateman et al. [29] but is contrary to Soheili et al. [39], who described a decrease of $\mathrm{T}_{\text {reg }}$ cells in 26 paediatric pa- 
tients of Iranian origin. Based on the previously observed expansion of $\mathrm{T}_{\text {reg }}$ cells in patients with chronic infections $[40,41]$, we suggest that the increase of $\mathrm{T}_{\text {regs }}$ may be associated with chronic immune activation in IgAD patients. You et al. in a previous study [42] described a decrease in the frequency of $\mathrm{T}_{\text {reg }}$ cells in CVID patients with autoimmunity compared both to patients without autoimmunity and healthy donors. Using this approach, we did not observe any similar findings in IgAD patients.

Our observation shows that terminally differentiated memory $\mathrm{T}$ cells are increased not only in CVID but also in IgAD patients. The increase in IgAD patients may be related to a different frequency of CMV infection in these persons. The observation of a higher frequency of CMV infection in IgAD patients deserves further study.

This work was supported by Ministry of Health of the Czech Republic, grants nr. 15-28541Aand 15-28732A.

The authors declare no conflict of interest.

\section{References}

1. Latiff AH, Kerr MA (2007): The clinical significance of immunoglobulin A deficiency. Ann Clin Biochem 44: 131-139.

2. Cunningham-Rundles C (2001): Physiology of IgA and IgA deficiency. J Clin Immunol 21: 303-309.

3. Chapel H, Cunningham-Rundles C (2009): Update in understanding common variable immunodeficiency disorders (CVIDs) and the management of patients with these conditions. Br J Haematol 145: 709-727.

4. Cunningham-Rundles C, Bodian C (1999): Common variable immunodeficiency: clinical and immunological features of 248 patients. Clin Immunol 92: 34-48.

5. Quinti I, Soresina A, Spadaro G, et al. (2007): Long-term follow-up and outcome of a large cohort of patients with common variable immunodeficiency. J Clin Immunol 27: 308-316.

6. Abolhassani H, Amirkashani D, Parvaneh N, et al. (2013): Autoimmune phenotype in patients with common variable immunodeficiency. J Investig Allergol Clin Immunol 23: 323-329.

7. Hammarström L, Vorechovsky I, Webster D (2000): Selective IgA deficiency (SIgAD) and common variable immunodeficiency (CVID). Clin Exp Immunol 120: 225-231.

8. Rezaei N, Abolhassani H, Kasraian A, et al. (2013): Family study of pediatric patients with primary antibody deficiencies. Iran J Allergy Asthma Immunol 12: 377-382.

9. Wright JJ, Wagner DK, Blaese RM, et al. (1990): Characterization of common variable immunodeficiency: identification of a subset of patients with distinctive immunophenotypic and clinical features. Blood 76: 2046-2051.

10. Nechvatalova J, Pikulova Z, Stikarovska D, et al. (2012): B-lymphocyte Subpopulations in Patients with Selective IgA Deficiency. J Clin Immunol 32: 441-448.

11. Vlková M, Thon V, Sárfyová M, et al. (2006): Age dependency and mutual relations in $\mathrm{T}$ and $\mathrm{B}$ lymphocyte abnormalities in common variable immunodeficiency patients. Clin Exp Immunol 143: 373-379.
12. Litzman J, Vlková M, Pikulová Z, et al. (2007): T and B lymphocyte subpopulations and activation/differentiation markers in patients with selective IgA deficiency. Clin Exp Immunol 147: 249-254.

13. Jaffe JS, Strober W, Sneller MC (1993): Functional abnormalities of CD8+ T cells define a unique subset of patients with common variable immunodeficiency. Blood 82: 192-201.

14. Melo KM, Carvalho KI, Bruno FR, et al. (2009): A decreased frequency of regulatory $\mathrm{T}$ cells in patients with common variable immunodeficiency. PLoS One 4: e6269.

15. Mouillot G, Carmagnat M, Gérard L, et al. (2010): B-cell and T-cell phenotypes in CVID patients correlate with the clinical phenotype of the disease. J Clin Immunol 30: 746-755.

16. Arandi N, Mirshafiey A, Jeddi-Tehrani M, et al. (2013): Evaluation of $\mathrm{CD} 4+\mathrm{CD} 25+\mathrm{FOXP} 3+$ regulatory $\mathrm{T}$ cells function in patients with common variable immunodeficiency. Cell Immunol 281: 129-133.

17. Aukrust P, Frřland SS, Müller F (1992): Raised serum neopterin levels in patients with primary hypogammaglobulinaemia; correlation to other immunological parameters and to clinical and histological features. Clin Exp Immunol 89: 211-216.

18. Litzman J, Nechvatalova J, Xu J, et al. (2012): Chronic immune activation in common variable immunodeficiency (CVID) is associated with elevated serum levels of soluble CD14 and CD25 but not endotoxaemia. Clin Exp Immunol 170: 321-332.

19. Young JL, Ramage JM, Gaston JS, Beverley PC (1997): In vitro responses of human CD45R0brightRA- and CD45R0RAbright $\mathrm{T}$ cell subsets and their relationship to memory and naive T cells. Eur J Immunol 27: 2383-2390.

20. Hamann D, Baars PA, Rep MH, et al. (1997): Phenotypic and functional separation of memory and effector human CD8+ T cells. J Exp Med 186: 1407-1418.

21. Sallusto F, Lenig D, Förster R, et al. (1999): Two subsets of memory $\mathrm{T}$ lymphocytes with distinct homing potentials and effector functions. Nature 401: 708-712.

22. Maenetje P, Riou C, Casazza JP, et al. (2010): A steady state of CD4+ T cell memory maturation and activation is established during primary subtype C HIV-1 infection. J Immunol 184: 4926-4935.

23. Conley ME, Notarangelo LD, Etzioni A (1999): Diagnostic criteria for primary immunodeficiencies. Representing PAGID (Pan-American Group for Immunodeficiency) and ESID (European Society for Immunodeficiencies). Clin Immunol 93: 190-197.

24. Liu W, Putnam AL, Xu-Yu Z, et al. (2006): CD127 expression inversely correlates with FoxP3 and suppressive function of human CD4+ T reg cells. J Exp Med 203: 1701-1711.

25. Thongpan M, Kitiyakara C, Louischaroen Y, et al. (2009): Analysis of Foxp3, CD25, and CD127 expressed on regulatory T cells in Thai subjects. Asian Pac J Allergy Immunol 27: 137-145.

26. Horn J, Manguiat A, Berglund LJ, et al. (2009): Decrease in phenotypic regulatory $\mathrm{T}$ cells in subsets of patients with common variable immunodeficiency. Clin Exp Immunol 156: 446-454.

27. Libri V, Azevedo RI, Jackson SE, et al. (2011): Cytomegalovirus infection induces the accumulation of short-lived, multifunctional CD4+CD45RA+CD27+ T cells: the potential involvement of interleukin-7 in this process. Immunology 132: 326-339. 
28. Mackus WJ, Frakking FN, Grummels A, et al. (2003): Expansion of CMV-specific CD8+CD45RA+CD27- T cells in B-cell chronic lymphocytic leukemia. Blood 102: 1057-1063.

29. Bateman EA, Ayers L, Sadler R, et al. (2012): T cell phenotypes in patients with common variable immunodeficiency disorders: associations with clinical phenotypes in comparison with other groups with recurrent infections. Clin Exp Immunol 170: 202-211.

30. Giovannetti A, Pierdominici M, Mazzetta F, et al. (2007): Unravelling the complexity of $\mathrm{T}$ cell abnormalities in common variable immunodeficiency. J Immunol 178: 3932-3943.

31. Warnatz K, Denz A, Dräger R, et al. (2002): Severe deficiency of switched memory B cells (CD27(+) $\operatorname{IgM}(-) \operatorname{IgD}(-))$ in subgroups of patients with common variable immunodeficiency: a new approach to classify a heterogeneous disease. Blood 99: 1544-1551.

32. Burgers WA, Riou C, Mlotshwa M, et al. (2009): Association of HIV-specific and total CD8+ T memory phenotypes in subtype C HIV-1 infection with viral set point. J Immunol 182: 4751-4761.

33. Marashi SM, Raeiszadeh M, Enright V, et al. (2012): Influence of cytomegalovirus infection on immune cell phenotypes in patients with common variable immunodeficiency. J Allergy Clin Immunol 129: 1349-1356.e3.

34. Papagno L, Spina CA, Marchant A, et al. (2004): Immune activation and CD8+ T-cell differentiation towards senescence in HIV-1 infection. PLoS Biol 2: E20.

35. Shen CY, Chang WW, Chang SF, et al. (1992): Seroepidemiology of cytomegalovirus infection among children between the ages of 4 and 12 years in Taiwan. J Med Virol 37: 72-75.

36. Mustakangas P, Sarna S, Ammälä P, et al. (2000): Human cytomegalovirus seroprevalence in three socioeconomically different urban areas during the first trimester: a population-based cohort study. Int J Epidemiol 29: 587-591.

37. Sakaguchi S. (2004): Naturally arising CD4+ regulatory $\mathrm{t}$ cells for immunologic self-tolerance and negative control of immune responses. Annu Rev Immunol 22: 531-562.

38. Cools N, Ponsaerts P, Van Tendeloo VF, Berneman ZN (2007): Regulatory T cells and human disease. Clin Dev Immunol 2007: 89195.

39. Soheili H, Abolhassani H, Arandi N, et al. (2013): Evaluation of natural regulatory $\mathrm{T}$ cells in subjects with selective IgA deficiency: from senior idea to novel opportunities. Int Arch Allergy Immunol 160: 208-214.

40. Freguja R, Gianesin K, Mosconi I, et al. (2011): Regulatory T cells and chronic immune activation in human immunodeficiency virus 1 (HIV-1)-infected children. Clin Exp Immunol 164: 373-380.

41. Punkosdy GA, Blain M, Glass DD, et al. (2011): Regulatory T-cell expansion during chronic viral infection is dependent on endogenous retroviral superantigens. Proc Natl Acad Sci U S A 108: 3677-3682.

42. Yu GP, Chiang D, Song SJ, et al. (2009): Regulatory T cell dysfunction in subjects with common variable immunodeficiency complicated by autoimmune disease. Clin Immunol 131: 240-253. 